\title{
Leipzig 2007
}

\author{
By Ron Holloway \\ Spring 2007 Issue of KINEMA
}

\section{$49^{\text {th }}$ LEIPZIG INTERNATIONAL FESTIVAL FOR DOCUMENTARY AND ANIMATION FILMS}

Under visionary Claas Danielson, now in his third year as festival director and aided by an equally energetic team, the $49^{\text {th }}$ Leipzig International Festival for Documentary and Animation Films (30 October- 05 November 2006), aka Dok Festival \& Dok Industry for visiting professionals, broke its previous statistical record once more. From 2,400 submissions, the festival booked just over 400 films from 50 countries, the total evenly divided between documentary and animation entries. Altogether, that amounts to 19,230 minutes viewing time, or 13 days, 8 hours, and 30 minutes in one sitting. This year's attendance climbed to 22,500, up from 20,000 in 2005. A total of Euro 53,500 was handed out to award winners in various categories.

Among the 259 events (including social events, reruns, and industry specials) was one key day that signalled a new direction for the festival. On November 1st, the "DOK Market Digital" was officially opened by the Saxon State Minister in the festival centre. If you were lucky, you could grab one of 20 viewing seats, then choose at a mouse-click from a digital library of 300 films, including all the festival's competition films, plus highlights of the past two years. Gone are the waiting lines for videos and DVDs. The event heralds the day when digital satellite transmission will be the norm for competition screenings at Leipzig and other key international film festivals. Gone, then, is the onus of missing film prints. That said, the forthcoming $50^{\text {th }}$ Leipzig festival - scheduled 29 October to 04 November 2007 - promises to be a crowning anniversary affair that should spotlight the DOKfest among the leaders on the international documentary circuit.

The familiar "Picasso Dove" - a symbolic peace gift from Picasso to the DOKfestival some four decades ago thanks to the intercession of prominent Russian journalist Vladimir Posner - is still visible on the festival trailer and catalogue cover. But the central motif of the 2006 DOK festival was something else - namely, a collage of faces appearing into the sky as though people are collectively witnessing the $9 / 11$ tragedy all over again. By the same token, one of the special programs - titled "Fake!" - aptly demonstrated how the lines between documentary and fiction are effectively rubbed out by filmmakers prone to pull the wool over the eyes of their audiences. Needless to say, the series was well attended, particularly Alexei Fedorchenko's Pervye na luna (The First on the Moon, Russia, 2005), a rib-tickling archival ploy that lays claim to the first space shuttle to the moon back in the glorious Soviet year of 1937. Another festival attraction was "Carte Blanche Otto Alder," a salute to the festival's previous animation programmer. Alder was invited to screen all his favourite animation films, among them Yuri Norstein's classic Skazka skazok (Tale of Tales, (Soviet Union, 1979) - "a film that touched my soul" (Alder)

Leipzig 49 opened with an entry from the German Documentary Competition: Ulrike Franke and Michael Loeken's Losers and Winners. Picture a large-scale Chinese dismantling team arriving at a Dortmund coking plant to cut the entire complex into pieces and then transport the whole via containers to China, where the entire factory will be reassembled and reactivated just like it was in Dortmund. Alone the comparing of working conditions, guaranteed German salaries plus safety regulations versus meagre Chinese wages earned by working demanding hours, says it all in this critical documentary that unfortunately wears thin over its 96-minute run. All the same, Winners and Losers impressed this viewer more than the Discovery Channel Winner in this category: Lars Barthel's Mein Tod ist nicht dein Tod (My Death, Not Yours, Germany-India), a rambling autobiographical tale about the director's love affair with the daughter of Indian communist when both were attending the Babelsberg film school back in GDR socialist days. Unfortunately overlooked for an award in this section was one of the festival's most impressive documentaries: Heidi Specogna's Das kurze Leben des José Antonio Gutierrez (The Short Life of José Antonio Gutierrez, Germany-Switzerland), a moving investigative account of the life and death of the first American soldier killed in Iraq. For Gutierrez was a Latino from Guatemala who carried only a Green Card while hoping to become an American citizen by joining the marines. 
The Golden Dove for Long Documentary was shared by Arash's Exile Family Movie (Austria) and Tali Shemesh's Moadon Beit Hakvarot ( The Cemetery Club, Israel), both family chronicles that pull at the heart strings. In Exile Family Movie the focus is on a large Iranian family living in the West and the East whose only hope of seeing each other is via a secretive rendezvous during a pilgrimage to Mecca - an amusing plan to skirt the authorities, to say the least. In The Cemetery Club we follow over a couple years how a group of senior citizens look forward to their regular Saturday morning rendezvous at the Mount Herzl national cemetery, where they engage in light cultural discussion to pass the time away and mourn the passing of club members. The Silver Dove was awarded to Mark Verkerk's Buddha's Lost Children (Netherlands-MyanmarThailand), an engrossing chronicle of the determination and struggle of a Buddhist monk, an ex-Thai boxer, to shelter and educate orphaned boys in his monastery in Thailand's north, where drug-dealers terrorize the community.

Several other long documentaries equally deserved award recognition. Sergei Loznica's Blokade (Blockade, Russia) mutely portrays the suffering and death of an estimated 800,000 citizens during the 900-day blockade of Leningrad (1941-44), relying entirely on archival footage and naturalistic sounds to take the pulse of the besieged city. Erich Langjahr's Das Erbe der Bergler (Alpine Saga, Switzerland), a sketch of Alpine mountaineers still cutting grass on the slopes above Muota Valley to provide fodder for their cattle in the winter. Alpine Saga the latest in Langjahr's lyrical ethnographic series that now began with Sennen-Ballade (Alpine Ballad) 1996), and continued with Bauernkrieg (Peasants'War, 1998) and Hirtenreise ins dritte Jahrtausend (Shepherd's Journey into the Third Millennium, 2002), awarded the Golden Dove at Leipzig. Heddy Honigmann's Forever (Netherlands) offers the viewer an unforgettable tour of the legendary Père Lachaise cemetery in Paris. And Stanley Nelson's Jonestown - The Life and Death of Peoples Temple (USA) uncovers some of the mysteries behind the mass suicide in 1978 of 900 followers in the doomsday cult of charismatic Jim Jones in the jungle of Guyana.

The Golden Dove for Best Short Documentary was deservedly awarded to Edgar Bartenev's ethnographic Japtik-Chese (Yaptik-Hasse, Russia). Running at just 29 minutes, we come to know intimately several members of the large nomadic Yaptik family living in the Tundra on the Yamal Peninsula, one but a year old and another a 90-year-old shaman who claims he's really his felt age of 35! Breath-taking images are interwoven with avant-garde and humorous intertitles as used in silent films. The Silver Dove went to Sonja Linden's Ei kikaan ole saari (No Man Is an Island, Finland), a poignant meditation on how an old man on a secluded island prepares for his last days among other duties that require his daily attention. Along similar lines was Uruphong Raksasad's Wan tee yao nan (The Longest Days, Thailand), an insightful portrait of two old women in rural Thailand whose primary occupation in waiting for death and its welcomed release from pain and loneliness. Last, but not least, Liu Wei's Wangque de yitian (A Day to Remember, China) need only 13 minutes to chronicle how Beijing citizens are still reluctant to remember the anniversary of the student uprising on Tiananmen Square in 1989.

In the International Documentary Program was a timely political film that drew a large audience and provoked lengthy discussion: Miroslaw Dembinski's Lekcja Bialoruskiego ( $A$ Lesson of Belorussian, PolandBelarus). Running at just under an hour, A Lession of Belorussian chronicles recent events in Belarus that saw President Lukashenka manipulating an election and putting down a peaceful sit-in demonstration by the opposition with force. The inside report by a filmmaker from neighbouring Poland also lends force to the overall document of suppression of free speech in Belarus.

The Golden Dove for Best Animation went to Run Wrake's Rabbit (UK), a picture-book treatise on the innocence of childhood marred by greed and violence. The Silver Dove was shared by Georges Schwizgebel's Jeu (Play, Switzerland), in which the letters J, E, and U are animated to the music of Prokofiev, and Florence Miailhe's Conte de quartier (France-Canada), an urban tale depicting seven characters in a striking "painting in motion" context.

The 49th Leipzig DOKfest will be remember for its retrospectives and tributes. For cineastes there were the homages to Canada's Allan King and Germany's Hans-Dieter Grabbe. Special Screenings honoured Poland's Krzysztof Kieślowski and Baltic Documentaries. In conjunction with a program of Arab Documentaries and China Day, a DOK Summit featured roundtable discussions on the "Clash of Civilizations." Indeed, with some twenty sections listed in the festival catalogue, Leipzig 49 was a collection of mini-festivals that could 
have easily stood alone on their own merits. The 50th DOKfest promises to be an even greater maze of documentary and animation viewing pleasure.

\section{References}

\section{AWARDS}

INTERNATIONAL COMPETITION

Golden Dove, Long Documentary - ex aequo

Exile Family Movie (Austria), dir Arash

Moadon Beit Hakvarot (The Cemetery Club, Israel),

dir Tali Shemesh

Silver Dove, Long Documentary

Buddha's Lost Children (Netherlands-Myamar-Thailand), dir Mark Verkerk

Golden Dove, Short Documentary

Yaptik-Chese (Yaptik-Hasse, Russia),

dir Edgar Bartenev

Silver Dove, Short Documentary

Ei kukaan ole saaari (No Man Is an Island, Finland), dir Sonja Linden

\section{Special Mention}

Jonestown - The Life and Death of Peoples Temple (USA), dir Stanley Nelson

Talent Dove - Sparkasse Leipzig Prize

Ine Svety (Other Worlds, Slovakia-Czech Republic), dir Marko Skop

Special Mention

Jack Smith and the Destruction of Atlantis (USA), dir Mary Jordan

GERMAN COMPETITION

Discovery Channel Film Prize

Mein Tod ist nicht dein Tod (My Death, Not Yours, Germany), dir Lars Barthel

\section{Special Mentions}

Eggesin möglicherweise (Eggesin ... Maybe, Germany), dir Olaf Winkler

Too Much Future - In Grenzen frei (Too Much Future), dir Carsten Fiebeler

\section{INTERNATIONAL ANIMATION COMPETITION}

Golden Dove

Rabbit (UK),

dir Run Wrake

Silver Dove - ex aequo

Conte de quartier (France-Canada),

dir Florence Miailhe 
Jeu (Play, Switzerland),

dir Georges Schwizgebel

Special Mentions

Schliess die Augen und atme nicht (Close Your Eyes and Do Not Breathe, Germany), dir Vuk Jevremović

Stalk (UK), dir Leigh Hodgkinson

Une instituut (Institute of the Dream, Estonia),

dir Mati Kütt

\section{OTHER AWARDS}

MDR (Mitteldeutscher Rundfunk) Film Prize for Eastern European Film

Lekcja Bialoruskiego (A Lesson of Belorussian, Poland-Belarus), dir Miroslaw Dembinski

\section{DEFA Grant Prize}

Eggesin möglicherweise (Eggesin ... Maybe, Germany), dir Olaf Winkler

ver.di (Media Trade Union) Prize

Tupakkatytöt (Tobacco Girls, Finland), dir Tarja Mattila

Ecumenical Jury

Forever (Netherlands),

dir Heddy Honigmann

FIPRESCI (International Critics) Awards

Documentary - Exile Family Movie (Austria),

dir Arash

Animation - Moja Ljubov (My Love, Russia), dir Alexandre Petrov

Leipzig Youth Jury Prize

Vikarien (The Substitute, Sweden), dir Asa Blanck, Johan Palmgren

Mephisto-97.6 Audience Prize

Pro Ivana-duraka (About Ivan the Fool, Russia), dir Mikhail Adashin, Oleg Uzhinov.

\section{Author Information}

Ron HOLLOWAY (1933-2009) was an American critic, film historian, filmmaker and correspondent who adopted Europe as his home in the early fifties and spent much of his life in Berlin. He was an expert on the study of German cinema and against all odds produced, with his wife Dorothea, the journal German Film, keeping us up-to-date with the work of directors, producers and writers and the showing of German films around the world.

In 2007, Ron Holloway and his wife were awarded the Berlinale Camera Award. Ron also received the Bundesverdienstkreuz (German Cross of Merit), Polish Rings, Cannes Gold Medaille, the American Cinema Foundation Award, the Diploma for Support of Russian Cinema and an honorary award from the German Film Critics' Association.

Ron was also a valued contributor to Kinema for the past fifteen years. 